\title{
Spatial heterogeneity in subtidal gravel generated by the pit-digging activities of Cancer pagurus
}

\author{
Simon F. Thrush* \\ School of Biological Sciences, University of East Anglia, Norwich NR4 7RTJ, England
}

\begin{abstract}
In a coarse gravelly substratum exposed to high current velocities the crab Cancer pagurus was observed to dig pits, approximately $30 \mathrm{~cm}$ in diameter and $10 \mathrm{~cm}$ deep. Experiments were conducted to identify macrobenthic recolonization processes and differences in abundance between pits and unmanipulated areas. Surveys of the abundance of recently dug pits indicate a frequency of approximately 9 pits $100 \mathrm{~m}^{-2}$. Analysis of species abundances in artificial pits at various times after construction revealed colonizing species to be highly variable. In a second experiment statistically significant differences in the abundances of various species were found between artificial pits and adjacent unmanipulated sediment, but trends in the data were not consistent between experiments. Generally, macrofaunal recolonization processes were haphazard. These results are contrasted with initial recolonization processes in soft sediments. The mobility and large particle size of the sediment are considered to be important in precluding predictable recolonization patterns.
\end{abstract}

\section{INTRODUCTION}

The influence of disturbance on community structure has been widely demonstrated, or inferred, from studies of many different habitats (reviewed by Sousa 1984). Disturbance may prevent a community from reaching competitive equilibrium (Connell 1978), provide extra resources (Thistle 1981) and, at intermediate intensities, increase diversity (Huston 1979). Studies of disturbance events in marine communities have concentrated on rocky shore and fine sediment habitats; little information is available on the role of disturbance in structuring the communities of mobile gravel-sand sediments. Localized disturbance resulting from predator feeding activity occurs in a variety of situations, ranging from small bites taken from the sediment by juvenile flatfish to the larger disturbances created by bottom-feeding whales (Oliver et al. 1984) and walrus (Oliver et al. 1983, 1985).

The experiments described in this paper were designed to assess macrofaunal recolonisation of pits and the variation in abundance of common species between pits and adjacent unmanipulated sediments by simulating the pit digging activities of Cancer pagurus (Linnaeus). Some measure of the frequency of

- Present address: Portobello Marine Laboratory, P.O. Box 8, Portobello, Dunedin, New Zealand the natural events was also made and this, coupled with the results of the experiments, allows an assessment of the importance of the phenomenon in determining the spatio-temporal pattern of community structure.

\section{MATERIALS AND METHODS}

Lough Hyne is a small sea-lough, approximately $1 \mathrm{~km}$ long and $750 \mathrm{~m}$ wide, situated in south-west Ireland $\left(51^{\circ} 30^{\prime} \mathrm{N}, 10^{\circ} 18^{\prime} \mathrm{W}\right)$. The lough is connected to the open sea via a shallow narrow channel (The Rapids) in which tidal currents achieve a maximum velocity of approximately $2 \mathrm{~m} \mathrm{~s}^{-1}$ (Bassindale et al 1957). This study was conducted to the floor of the lough, at the base of a shell-gravel ramp leading down from The Rapids, at a depth of approximately $19 \mathrm{~m}$. The sediment in this area has a median particle size of $1.68 \mathrm{~mm}$ and is composed of approximately $50 \%$ gravel, $35 \%$ sand and $8 \%$ silt-clay. The organic matter content of the sediment is approximately $3 \%$ (Thrush \& Townsend in press).

An experiment was established in August 1983 to follow the colonization of crab pits by macrofauna. An array of 14 pits was dug, using a small shovel, to a shape and depth designed to mimic natural crab pits with a mean diameter $30 \mathrm{~cm}$ (range 27 to $33 \mathrm{~cm}$ ) and a 
mean depth of $10 \mathrm{~cm}$ (range 9 to $12 \mathrm{~cm}$ ). The pits were spaced $1 \mathrm{~m}$ apart and arranged in 2 rows perpendicular to current flow. The position of each pit was marked with a small flag. The experimental area was checked twice a week and cleared of any drifting debris. Samples were collected from 2 different, randomly selected, artificial pits on each of 6 occasions; $1,7,15$, 21,26 and $48 \mathrm{~d}$ after the start of the experiment. Two core samples $(5 \mathrm{~cm}$ diameter, $10 \mathrm{~cm}$ depth) were collected from each pit. Seventeen d after the initiation of this experiment 15 core samples were collected from an adjacent area $\left(50 \mathrm{~m}^{2}\right)$ of unmanipulated sediment. Samples were collected from random positions using cartesian co-ordinates, but excluded obvious natural crab pits. Macrofaunal samples were fixed $(4 \%$ buffered formaldehyde in seawater), stained (1\% Rose Bengal) and sieved (0.5 mm mesh size). Macrofauna were counted and identified to the lowest possible taxa.

Rank/abundance diagrams have been used as a method of representing the distribution of individuals amongst species within the community (see Whittaker 1975). Such graphs display community composition and allow a degree of biological interpretation not possible with single number diversity and equitability measures. In this study, rank/abundance curves are used simply to illustrate differences in numerical dominance and in the presence of rare species between treatments and the adjacent unmanipulated area. Significant differences in the dominance of the most abundant species and total number of individuals were assessed using the Kruskal-Wallis statistic (Conover 1980).

To improve the power of statistical comparisons of species abundances in experimental pits with the surrounding unmanipulated area, a second experiment was designed. Ten pits were dug in June 1984 and their positions were marked in the sediment. Twiceweekly dives were undertaken over this area to monitor the course of the experiment. Twenty-two d after the pits were dug, 2 cores $(5 \mathrm{~cm}$ diameter, $10 \mathrm{~cm}$ deep) were taken from each of 7 pits; the remaining 3 could not be located. In an adjacent unmanipulated area 14 core samples were coljected from random posi- tions (excluding obvious crab pits) over an area of $50 \mathrm{~m}^{2}$. The significance of differences in the abundance of common species between artificial crab pits and the adjacent unmanipulated area was assessed using the Mann-Whitney statistic (Conover 1980).

Five surveys were conducted in the period June to August 1984 to assess the abundance of crab pits, and to determine the diameter and depth of pits and the number occupied by crabs. All pits in a band $2.5 \mathrm{~m}$ on either side of a $90 \mathrm{~m}$ transect line were counted and measured. The full length of the transect line could not always be covered on each survey owing to dive schedules. The transect line was left in place between surveys as it was hoped to follow the history of individual pits, though this proved impossible. At the end of the transect line 3 artificial pits were dug to monitor changes in surface sediment organic matter content and shear strength, associated with the infilling of pits. These pits were sampled $0,7,15,24,33$ and $41 \mathrm{~d}$ after they were dug. Sediment shear strength was analysed using a Pilchon Shear Vane stuck into the sediment to a depth of approximately $5 \mathrm{~cm}$. Sediment shear stress is a useful indicator of many sediment geophysical properties and is also related to changes in bioturbatory behaviour of species associated with different successional stages (see Rhoads \& Boyer 1982). A sample of sediment was collected from the surface of each pit for the determination of organic matter content, by combustion of dried $\left(60^{\circ} \mathrm{C}\right)$ sediment at $450^{\circ} \mathrm{C}$ for $24 \mathrm{~h}$ (Jørgensen 1977).

\section{RESULTS}

Survey data on the number of areas disturbed by the pit digging of Cancer pagurus are conservative because only very recently dug pits could be positively identified. Infilling of pits occurred rapidly, with the collapse of pit walls and movement of stones and gravel on the inflowing current (author's pers. obs.). After approximately $2 \mathrm{wk}$, pits could not be positively identified. However, an average of approximately 9 pits were identified for every $100 \mathrm{~m}^{2}$ (Table 1). Most pits tended to be elliptical in outline, tapering to the

Table 1. Number of crab pits recorded in surveys across the gravelly sediment of the South Basin

\begin{tabular}{|ccccc|}
\hline Date of survey & Area surveyed $\mathrm{m}^{2}$ & $\begin{array}{c}\text { Total number } \\
\text { of pits recorded }\end{array}$ & $\begin{array}{c}\text { Number of pits } \\
\text { per } 100 \mathrm{~m}^{2}\end{array}$ & $\begin{array}{c}\text { Percentage of pits occupied } \\
\text { by Cancer pagurus }\end{array}$ \\
\hline 26 Jun 84 & 450 & 77 & 17 & 17 \\
17 Jul 84 & 425 & 63 & 15 & 19 \\
28 Jul 84 & 375 & 41 & 11 & 5 \\
8 Aug 84 & 225 & 42 & 19 & 5 \\
16 Aug 84 & 450 & 40 & 9 & 5 \\
\hline
\end{tabular}




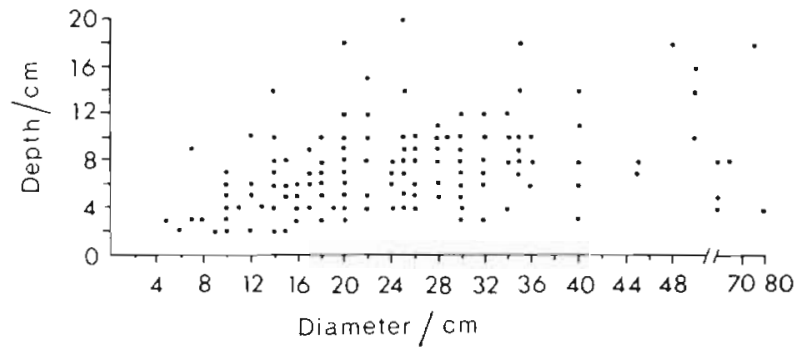

Fig. 1. Relation between maximum width and maximum depth of crab pits, based on a survey of 263 pits

deepest point. The relation between individual pit diameters and depth is shown in Fig. 1. On average approximately $10 \%$ of the pits were actually occupied by Cancer pagurus. Occupation of any particular depression was unpredictable; crabs were not generally observed to remain in pits. However, the largest pits appeared to contain long-term residents, as recognizable individuals were seen repeatedly in these pits.

These large pits were different in shape to the others, having flat bottoms and high walls. On many occasions crabs were observed excavating pits. The process involved disturbing the sediment with the legs and bulldozing material out of the areas with the claws. This process was most frequently observed during flood tides, when plumes of the finer sediments disturbed by the crabs could be seen drifting downstream. Artificial pits used in experimental studies closely resembled natural ones, not only in initial shape and size but also in their infilling tendency.

A comparison of surface sediment shear strength (in tonnes $\mathrm{m}^{-2} \simeq 10 \mathrm{kPa}$ ) between sediments artificially disturbed to resemble crab pits and adjacent unmanipulated areas is shown in Table 2. Casual measurements also indicated similar sediment shear strengths in newly formed real pits $(0.30$ to 0.38 tonnes $\left.\mathrm{m}^{-2}\right)$. A pattern of lower shear strength, especially shortly after the pits were dug, was apparent in experi-

Table 2. Comparison of sediment shear strength (tonnes $\mathrm{m}^{-2}$ ) between areas artificially disturbed to resemble Cancer pagurus excavations and unmanipulated areas

\begin{tabular}{|lcccc|}
\hline $\begin{array}{l}\text { Time after } \\
\text { estabishment } \\
\text { of pit (d) }\end{array}$ & \multicolumn{5}{c|}{$\begin{array}{c}\text { Sediment shear strength tonnes } \mathrm{m}^{-2} \\
\text { Median value }(\mathrm{n}=3) \\
\end{array}$} & Pit 1 & Pit 2 & Pit 3 & $\begin{array}{c}\text { Range for } \\
\text { unmanipulated } \\
\text { area }(\mathrm{n}=3)\end{array}$ \\
\hline 0 & & & & \\
7 & 0.35 & 0.35 & 0.40 & $0.42-0.50$ \\
15 & 0.26 & 0.20 & 0.26 & $0.41-0.42$ \\
24 & 0.20 & 0.32 & 0.32 & $0.40-0.50$ \\
33 & 0.30 & 0.43 & 0.50 & $0.40-0.55$ \\
41 & 0.32 & 0.42 & 0.34 & $0.32-0.42$ \\
& 0.30 & 0.36 & 0.45 & $0.40-0.50$ \\
\hline
\end{tabular}

mental pits. Measurements of organic matter content from artificial pits and unmanipulated areas did not show any clear differences (Table 3). Thus while sediment shear strength may be reduced in pits, probably resulting from the rearrangement of the sediment matrix on infilling, pits do not appear to act as traps for the deposition of fine material of high organic matter content.

\section{Experiment 1}

The sequential variations in the abundance of common species collected from artificial crab pits up to $48 \mathrm{~d}$ after disturbance are shown in Fig. 2; data are given as median and range of medians between repli-

Table 3. Comparison of sediment organic matter content between areas artificially disturbed to resemble Cancer pagurus excaviations and unmanipulated areas

\begin{tabular}{|c|c|c|c|c|}
\hline \multirow{2}{*}{$\begin{array}{l}\text { Time after } \\
\text { estabishment } \\
\text { of pit (d) }\end{array}$} & \multicolumn{4}{|c|}{$\begin{array}{l}\text { Percentage organic matter (after } \\
\text { sample combustion at } 450^{\circ} \mathrm{C} \text { for } 24 \text { h) }\end{array}$} \\
\hline & Pit 1 & Pit 2 & Pit 3 & $\begin{array}{l}\text { Range of values from } \\
\text { unmanipulated areas } \\
\qquad(\mathrm{n}=3)\end{array}$ \\
\hline 0 & 2.27 & 2.01 & 2.20 & $\cdot$ \\
\hline 7 & 2.32 & 2.14 & $\cdot$ & $2.39-3.03$ \\
\hline 15 & 2.09 & 2.02 & 2.08 & $1.79-2.52$ \\
\hline 24 & 2.32 & 2.94 & 2.76 & $1.89-2.78$ \\
\hline 33 & 2.21 & 2.34 & 6.40 & $2.25-2.93$ \\
\hline 41 & 1.85 & 2.39 & 2.72 & $2.03-2.80$ \\
\hline
\end{tabular}

cates. These figures are contrasted with the Wilcoxon median abundance and $95 \%$ confidence intervals for the adjacent unmanipulated area. The abundance of common species tended to be higher in crab pits than in adjacent unmanipulated areas. The polychaetes Paradoneis lyra (Southern) and Capitella spp. (as members of a supra-species complex; Grassle \& Grassle 1977) showed more or less constant levels of abundance throughout the experiment. Protodorvillia kefersteini (Mclntosh) (Polychaeta) showed a rapid increase in abundance at $21 \mathrm{~d}$ after the disturbance. Variation in the total number of individuals and number of species throughout the duration of the experiment and in the adjacent unmanipulated area are shown in Fig. 3. An increase in the abundance of individuals and number of species was evident by $21 \mathrm{~d}$ after disturbance.

Rank/abundance diagrams for the 6 sampling dates after disturbance, as compared to that in the adjacent unmanipulated area, are shown in Fig. 4. Initially, a low number of species were recorded from experimen- 
tal crab pits. Species rapidly entered the pits, but by the end of the experiment a greater number of species were still to be found in the adjacent unmanipulated area. The polychaetes Capitella spp., Paradoneis lyra and Pomatoceros spp. were numerically dominant species in both disturbed and unmanipulated areas. Protodorvillia kefersteini ranked higher in disturbed areas. No significant variation between sampling occasions is recorded in the proportional dominance of the most abundant species or total number of species $(\mathrm{H}$ : $\mathrm{p}>0.05$ ).

The results of this experiment indicate that species

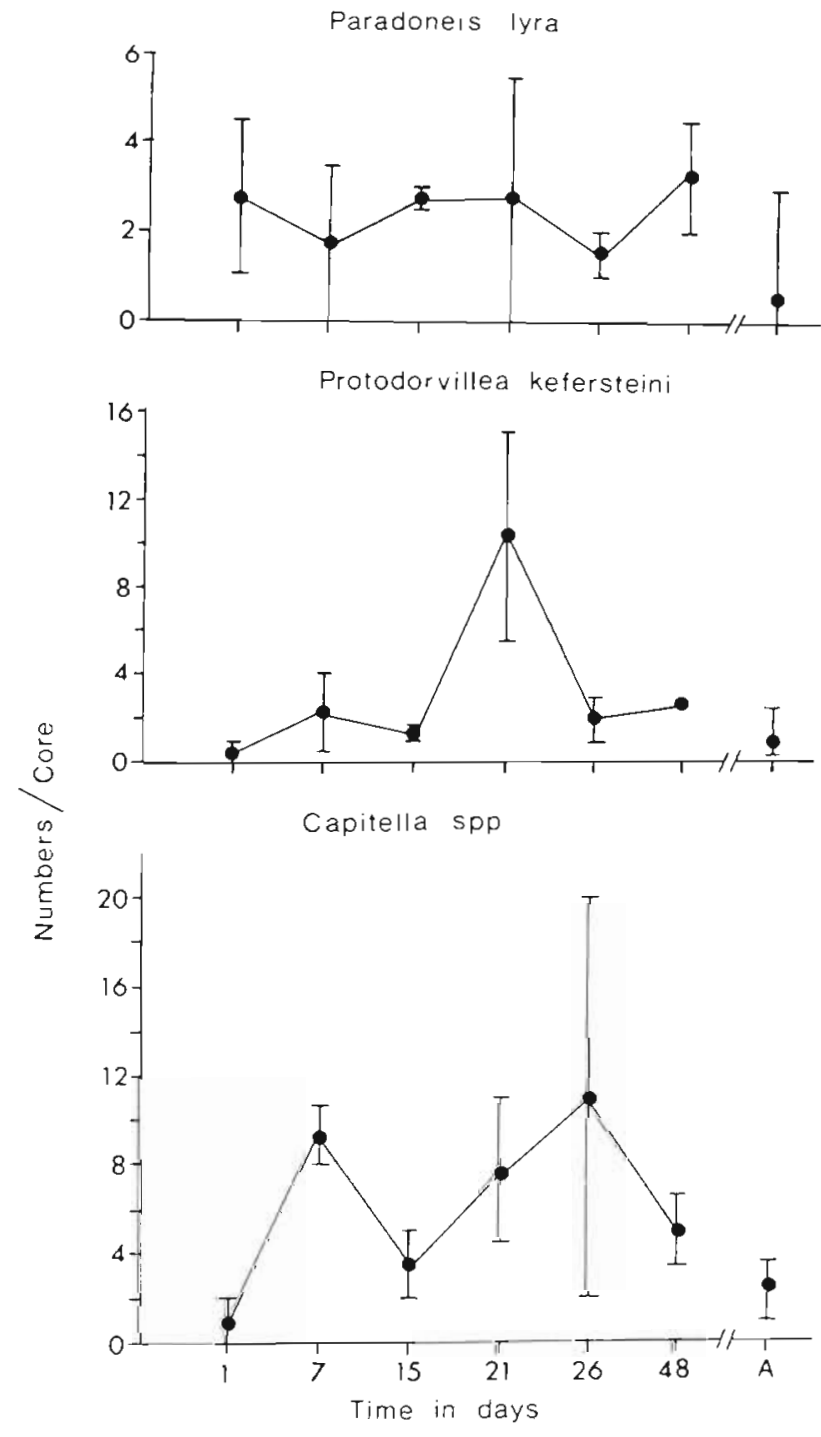

Fig. 2. Variation in the abundance of common species recorded at successive intervals after disturbance, contrasted with abundance in the adjacent unmanipulated area (A). Abundance estimates for experimental samples represent overall median abundance; error bars represent range of medians between replicates. Abundance estimates from the adjacent unmanipulated area are the Wilcoxon median and approximate $95 \%$ confidence intervals are removed from excavated areas. Recolonization of the pits appears to be rapid. Protodorvillia kefersteini is the only species which appears to show drastic changes in abundance during the recolonisation process. Generally, the results of this experiment are inconclusive partly because of the low number of replicates sampled at any one time. However, even taking this into account the abundance of organisms within experimental samples does seem to be remarkably variable.

\section{Experiment 2}

Differences in the abundance of common species in unmanipulated areas and areas exposed to simulated crab digging disturbance $22 \mathrm{~d}$ prior to sampling are

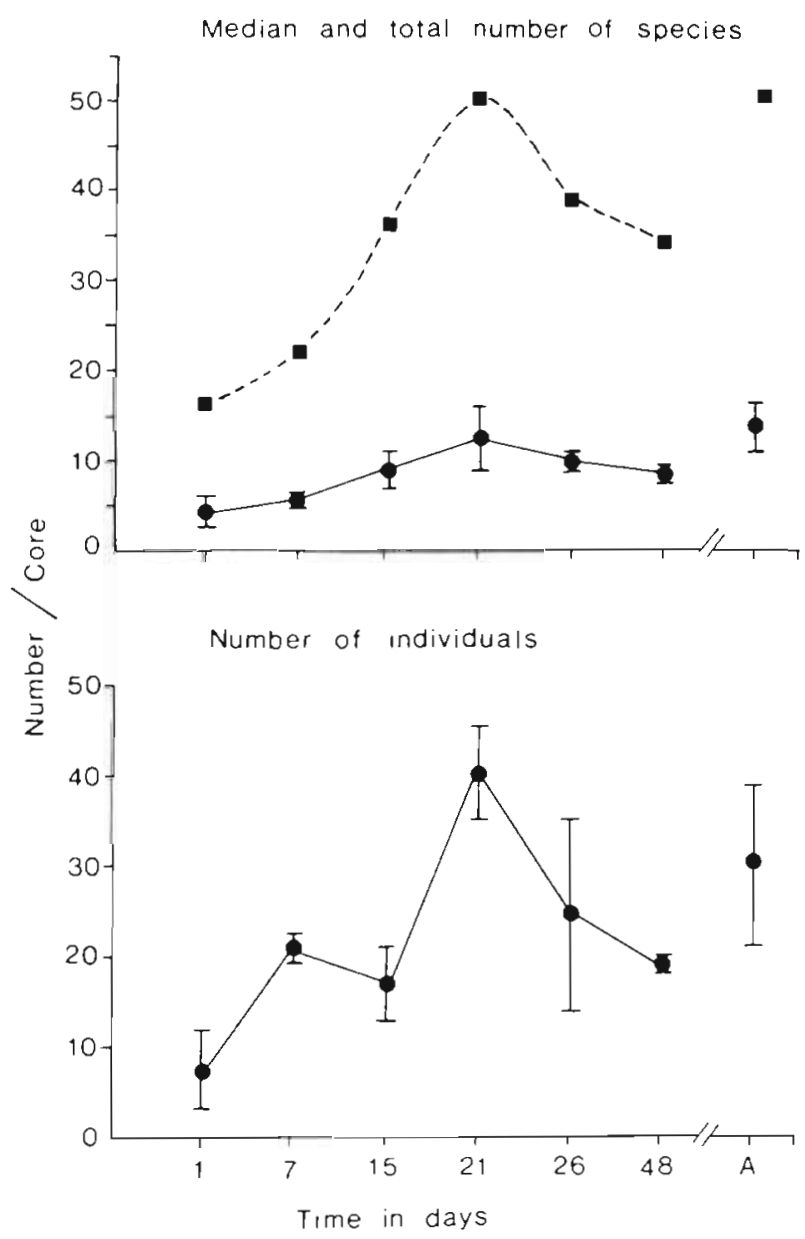

Fig. 3. Variation in median and total number of species and median number of individuals recorded at successive intervals after disturbance, contrasted with abundance in the adjacent unmanipulated area (A). Abundance estimates for experimental samples represent overall median abundance; error bars represent range of medians between replicates. Abundance estimates from the adjacent unmanipulated area are the Wilcoxon median and approximate $95 \%$ confidence intervals 


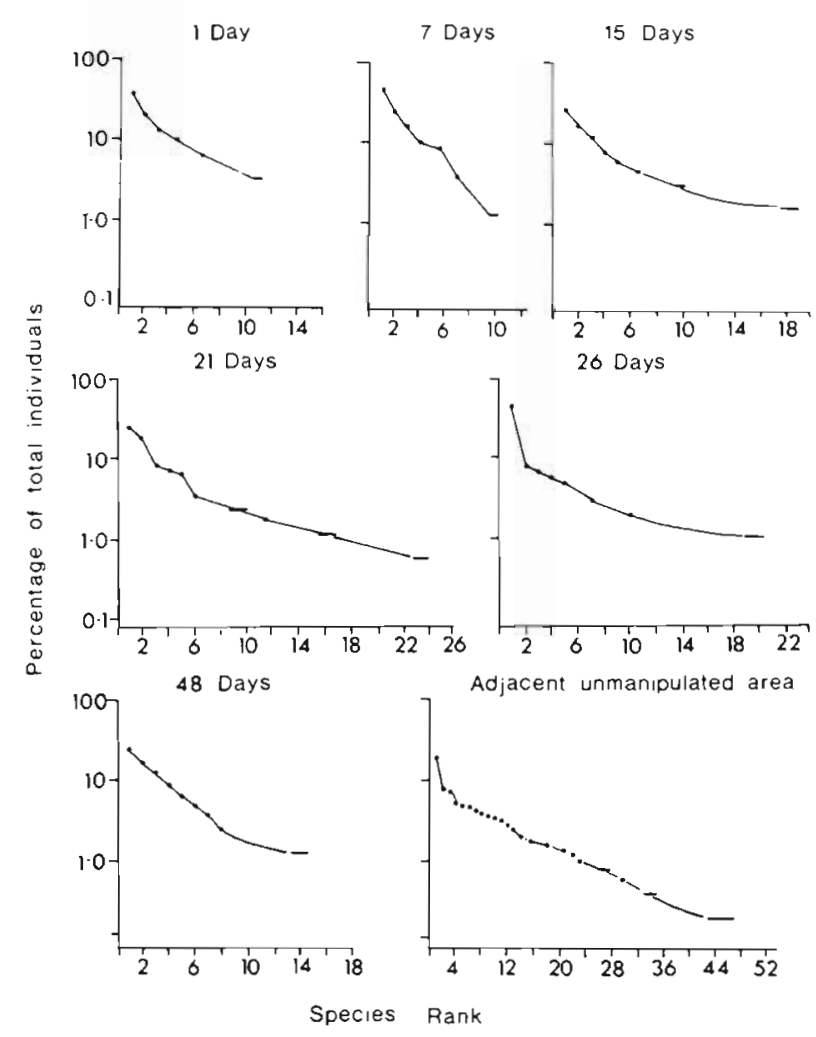

Fig. 4. Rank/abundance diagrams contrasting variation in the distribution of individuals amongst species on successive sampling occasions after disturbance and in the adjacent unmanipulated area

shown in Fig. 5. Scalibregma inflatum Rathke (Polychaeta) and Amphiopholis squamata (delle Chiaje) (Ophiuroidea) both showed a significantly higher abundance in the unmanipulated area (MannWhitney: $p<0.005: p<0.05$ respectively). In contrast, the polychaete Diplocirrus glaucus (Malmgren) and the bivalve Pavicardium ovale (Sowerby) were more abundant in pits than unmanipulated areas (MannWhitney: $p<0.05: p<0.01$ respectively). It is notable that in Experiment 2 no significant increases in abundance were observed in crab pits of those species which tended to increase in Experiment 1.

\section{DISCUSSION}

This study has demonstrated that the pit digging activities of Cancer pagurus result in short-term localized changes in benthic community structure. Similarly, the spatial and temporal heterogeneity described in a sand epifaunal community by Davis \& Van Blaricom (1978) was influenced by the pit-digging activities of foraging rays (Van Blaricom 1982). These pits were generally similar in size to those generated by Cancer pagurus in Lough Hyne. Ray pits accumulated organic matter, and thus provided localized patches of resources in an area of generally low organic matter deposition and retention, rather than providing a habitat free from competitors. In artificially generated crab pits, no significant variation in surface sediment organic matter content in comparison to unmanipulated areas was apparent. The gravelly sediment at the entrance to Lough Hyne is very mobile; sediment was frequently observed moving across the bottom and falling into depressions on inflowing tides. This will contribute to the highly variable conditions within pits. Thus, the assumption that the response of the benthic fauna within pits of similar age and size is comparable may not be wholly valid, as some pits may have slightly different histories producing important habitat differences. The disturbance generated by collecting core samples from individual pits was consi-

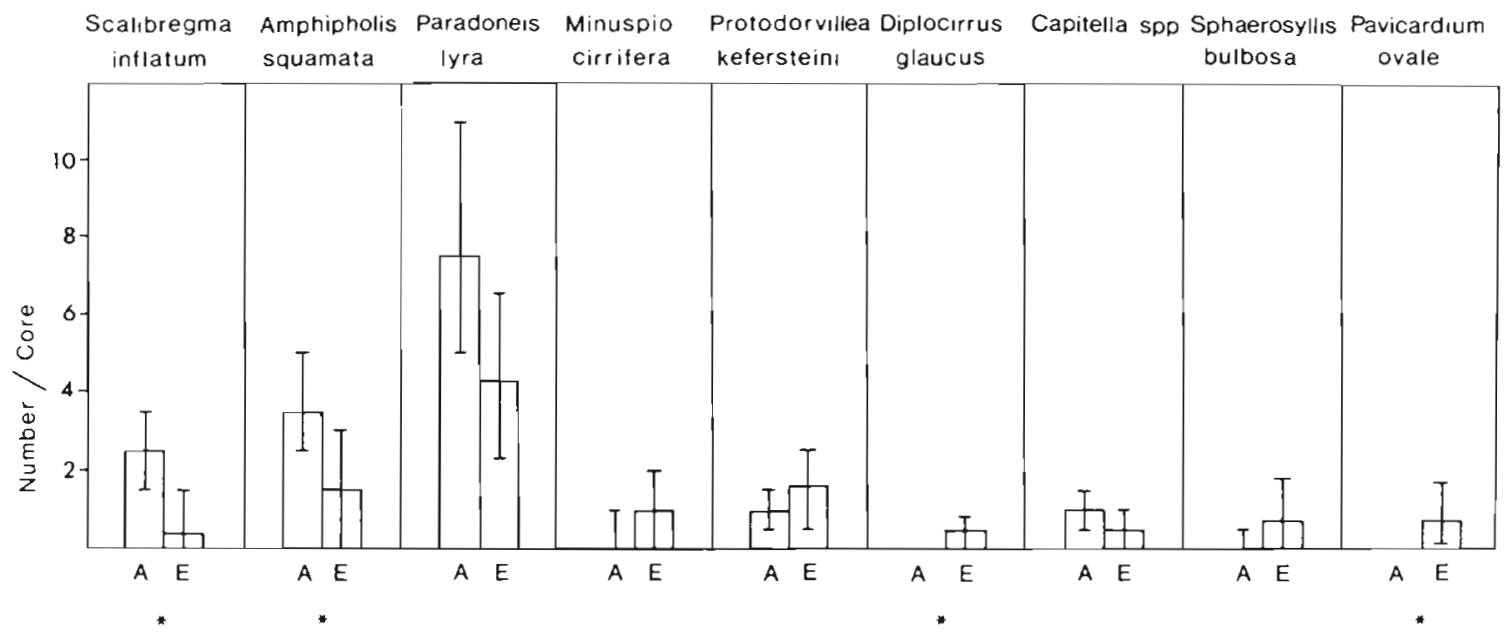

Fig. 5. Contrasts in the abundances of species between areas which had previously been disturbed (E) and adjacent unmanipulated areas (A). Each bar represents the Wilcoxon median and approximate $95 \%$ confidence intervals. Asterisks indicate significant differences in species abundances 
dered to invalidate successive sampling within each pit. This, and the inability to sample a real control area (i.e. not naturally exposed to the digging activities of Cancer pagurus) are constraints on the ability to interpret the results of the experiments. However, even taking into account these limitations and the small number of replicates, recolonization of experimental crab pits does show a remarkably high degree of variability. Rapid movement of adults into, and possibly out of pits, may further complicate the situation.

Early colonist species of ray pits were adult individuals of species capable of nocturnal swimming behaviour (Van Blaricom 1982). Migration of adults is likely also to be of importance in the recolonization of crab pits, as mature individuals were collected from experimental pits and unmanipulated areas, and is perhaps of more significance overall in areas of high water movement. Some polychaete genera found within the gravelly sediment of Lough Hyne contain species which are capable of using nocturnal swimming behaviour as a method of dispersion (e.g. Spherosyllis hystrix, Protodorvillia gracilis and Nematonereis unicornis in Alldredge \& King 1980). Adult migration by bivalves has also been demonstrated (Ansell \& Trevallion 1969, Ansell et al. 1972).

As water flows over and into a depression it will tend to slow down, reducing shear stress and enhancing the deposition of flocculent material (Nowell \& Jumars 1984). In the inflow area of Lough Hyne, where current strength changes drastically from maximum flood to ebb tides, the situation may be more complex. Material may be deposited in depressions at certain stages of the tidal cycle only to be scoured out at other times. Moreover, initial colonization of gravelly sediments by micro-organisms may have a less significant influence on the nature of gravelly sediments in comparison to muddy sediments. Mucus coating will not significantly affect grain to grain adhesion, lower bacterial biomass will offer less resources to colonizing meio- and macrofauna and also gravelly sediments are less likely to develop a near-surface redox potential discontinuity. Colonizing meio- and macrofauna in muddy sediments substantially manipulate the sediment, mixing and pumping water through the surface layers as well as constructing tubes, burrows, fecal mounds and pelletizing sediment (see McCave 1976, Rhoads \& Boyer 1982, Probert 1984). Although some species from this habitat may build tubes (e.g. Minuspio cirrifera; Foster 1971), generally the large particle size and mobility of the sediment reduce bioturbatory activities. These features may provide unsuitable and inconsistent conditions for blanket larval settlement of initial colonizing macrofauna. Rather, these areas are colonized to a greater extent by species with behavioural strategies adapted to mobility of post-recruitment stages. The lack of structures such as tubes and burrows and the mobility of the species found in gravelly sediment will influence the impact on the community of localized disturbance and the predictability of recolonization.

All crab pits do not necessarily offer resources to colonizing species. Any material deposited in pits may be scoured out during periods of high current velocity associated with the inflowing tide. Moreover, if there are marked variations in the history of individual pits, after they have been excavated, recolonization of these areas may follow a very haphazard pattem. No species becomes particularly abundant and this indicates that pits generally do not provide areas free from competitors or concentrate resources. Nevertheless, digging activity of Cancer increases the patchiness of individual species distributions and consequently the heterogeneity of community structure.

Acknowledgements. I would like to thank Professor J. A. Kitching and Dr. C. R. Townsend for their help with this work. This study would not have been possible without the assistance of my many dive partners, especially Guy Beard and Lloyd Czaplewski. Portobello Marine Laboratory and the Zoology department, University of Otago, provided facilities during the production of this manuscript. Drs J. B. Jillett, C. R. Townsend and 2 anonymous reviewers commented on an early draft. Funding for this study was provided by a University of East Anglia postgraduate scholarship and a CVCP overseas students fees award. The Department of Fisheries and Forestry, Ireland, provided permission for this work to be conducted within the Lough Hyne Marine Reserve.

\section{LITERATURE CITED}

Alldredge, A. L., King, J. M. (1980). Effects of moonlight on the vertical migration patterns of demersal zooplankton. $\mathrm{J}$. exp. mar. Biol. Ecol. 44: 133-156

Ansell, A. D., Treavallion, A. (1969). Behavioural adaptations of intertidal molluscs from a tropical sandy beach. $J$. exp. mar. Biol. Ecol, 4: 9-35

Ansell, A. D., Sivadas, P., Narayanan, B., Trevallion, A (1972). The ecology of two sandy beaches in south west India. III. Observations on the population of Dona incarnatus and D. spiculum. Mar. Biol. 17: 318-332

Bassindale, R., Davenport, E., Ebling, F. J., Kitching, J. A., Sleigh, M. A., Sloane, J. F. (1957). The ecology of Lough Ine Rapids with special reference to water currents. VI. Effects of the Rapids on the hydrography of the South Basin. J. Ecol. 45: 879-900

Connell, J. H. (1978). Diversity in tropical rainforests and coral reefs. Science 199: 1302-1310

Conover, W J. (1980). Practical nonparametric statistics. 2nd edn. J. Wiley \& Sons, New York

Davis, N., Van Blaricom, G. R. (1978). Spatial and temporal heterogeneity in a sand bottom epifaunal community of invertebrates in shallow water. Limnol. Oceanogr 23 : $417-427$

Foster, N. M. (1971). Spionidae (Polychaeta) of the Gulf of Mexico and the Caribbean Sea. Stud. Fauna Curaçao 36: $1-183$

Grassle, J. F., Grassle, J. P. (1977). Temporal adaptations in sibling species of Capitella. In: Coull, B. C. (ed.) Ecology 
of marine benthos. Univ, of South Carolina Press, Columbia, p. 177-189

Jorgensen, B. B. (1977). The sulfur cycle of a coastal marine sediment (Limfjorden, Denmark). Limnol. Oceanogr. 22 $814-831$

Huston, M. (1979). A general hypothesis of species diversity Am. Nat. 113: 81-101

McCave, I. N. (1976). The benthic boundary layer. Plenum Press, New York

Nowell, A. R. M., Jumars, P. A. (1984). Flow environments and aquatic benthos. Ann. Rev, Ecol. Syst. 15: 303-328

Probert, P. K. (1984). Disturbance, sediment stability, and trophic structure of soft-bottom communities. J. mar. Res. 42: 893-921

Oliver, J. S., Kvitek, R. G., Slattery, P. N. (1985). Walrus feeding disturbance: Scavenging habitats and recolonization of the Bering sea benthos. J. exp. mar. Biol. Ecol. 91: 233-246

Oliver, J. S., Slattery, P, N., O'Connor, E. F., Lowry, L. F (1983). Walrus, Ododenus rosmarus, feeding in the Bering Sea: A benthic perspective. Fish. Bull. U.S. 81: 501-512

Oliver, J. S., Slattery, P. N., Siberstein, M. A., O'Connor, E. F
(1984). Gray whale feeding on dense ampelisicid amphipod communities near Bamfield, British Columbia. Can. J. Zool. 62: 41-49

Rhoads, D. C., Boyer, L. F. (1982). The effects of marine benthos on physical properties of sediments. A successional perspective. In: McCall, P. L., Tevesz, M. J. S. (ed.) Animal-sediment relations. Plenum Press, New York p. $3-52$

Sousa, W. P. (1984). The role of disturbance in natural communities. Ann. Rev. Ecol. Syst. 15: 353--391

Thistle, D. (1981). Natural physical disturbances and communities of marine soft bottoms. Mar. Ecol. Prog. Ser. 6: 223-228

Thrush, S. F., Townsend, C. R. (in press). The sublittoral macrobenthic community composition of Lough Hyne, Ireland. Estuar. coast. Shelf Sci.

Van Blaricom, G. R. (1982). Experimental analysis of structural regulation in a marine sand community exposed to oceanic swell. Ecol. Monogr., 52: 283-285

Whittaker, R. H. (1975). Communities and ecosystems. 2nd edn. Macmillan, New York

This article was presented by Professor J. Gray; it was accepted for printing on March 12, 1986 